\section{Effect of various} irrigation solutions on cytokine expression of human gingival fibroblast: in vitro study

\section{Farklı irrigasyon solüsyonlarının insan fibroblast hücreleri üzerinde sitokin ekspresyonuna etkisi: in vitro çalışma}

\section{Assist. Prof. Zeliha Uğur Aydın} University of Abant Izzet Baysal, Faculty of Dentistry, Department of Endodontics, Bolu Orcid ID: 0000-0002-1773-9114

Assoc. Prof. Kerem Engin Akpınar

Cumhuriyet University, Faculty of Dentistry,

Department of Endodontics, Sivas

Orcid ID: 0000-0001-8900-9519

\section{Assist. Prof. Ceylan Hepokur}

Cumhuriyet University, Faculty of Dentistry,

Department of Endodontics, Sivas

Orcid ID: 0000-0001-6397-1291

Assist. Prof. Merve Alpay

Duzce University, Faculty of Medicine,

Department of Biochemistry, Duzce

Orcid ID: 0000-0002-8782-9561

Assoc. Prof. Demet Altunbas

Cumhuriyet University, Faculty of Dentistry,

Department of Endodontics, Sivas

Orcid ID: 0000-0002-7532-4785

Received: 2 April 2018

Accepted: 16 October 2018

doi: 10.5505/yeditepe.2019.96268

\section{Corresponding author:}

Assist. Prof. Zeliha Uğur Aydın

Abant Izzet Baysal University Faculty of Dentistry

Department of Endodontics Bolu, Turkey

Phone: +90 3742538455

Email: zlhugur@gmail.com

\section{SUMMARY}

Aim: The aim of this study is to investigate the release of IL-1, TNF- $\alpha$ and VEGF following administration of $\mathrm{NaOCl}$, propolis and chitosan solutions on human gingival fibroblasts.

Materials and Methods: This study was conducted on human fibroblast by cell culture and evaluation of the direct effect of various solutions on the cultured cells. The release of pro-inflammatory interleukin (IL), tumor necrosis factor (TNF) $\alpha$ and vascular endothelial growth factor (VEGF) on fibroblast was analyzed after administration of irrigation solutions. Log concentrations of $\mathrm{NaOCl}$, Propolis and Chitosan effects on cells were measured by colorimetric method.

Results: IL-1 and TNF- $\alpha$ secretion levels decreased during propolis and chitosan applications, which are natural products. It was also found that the propolis increased VEGF secretion more than the other materials.

Conclusions: The results of this study suggest that propolis and chitosan may contribute to the recovery of periapical tissues via anti-inflammatory cytokines level secreted during the inflammatory process. It is important to search for the biological effect of the materials in contact with the direct or indirect cause of the surrounding tissues during the endodontic treatment.

Keywords: Chitosan, cytokine, irrigation solutions, gingival fibroblast, propolis.

ÖZET

Amaç: Bu çalışmanın amacı human fibroblast hüre hattı üzerinde $\mathrm{NaOCl}$, propolis ve kitosan solüsyonlarının uygulanmasının ardından IL-1, Tnf-a ve VEGF salınımını araştırmaktır.

Gereç ve Yöntem: Bu çalışma, insan fibroblast hücre hattı üzerinde farkıı irrigasyon solüsyonlarının doğrudan uygulanmasının ardından oluşan etkinin değerlendirilmesiyle gerçekleştirilmiştir. İrrigasyon solüsyonlarının uygulanmasının ardından fibroblast hücresi üzerindeki pro-inflamatuar interlökin (IL), tümör nekrozis faktörünün (TNF) $\alpha$ ve vasküler endotelyal büyüme faktörünün (VEGF) salınımı analiz edildi. Hücreler üzerindeki $\mathrm{NaOCl}$, Propolis ve Kitosan etkilerinin log konsantrasyonları kolorimetrik yöntemle ölçüldü.

Bulgular: Doğal materyaller grubunda bulunan propolis ve kitosan solüsyonlarının uygulaması ile IL-1 ve TNF- $\alpha$ sekresyonu azaldı(p. Propolisin VEGF sekresyonunu diğer solüsyonlardan daha fazla artırdığı bulundu $(p<0.05)$.

Sonuç: Bu çalışmanın sonuçları, propolis ve kitosanın, inflamatuvar süreç sırasında salgılanan antiinflamatuar sitokinler aracılığıyla periapikal dokuların iyileşmesine katkıda bulunabileceğini düşündürmektedir. Endodontik tedavi sırasında çevredeki dokulara doğrudan veya dolaylı olarak temas eden maddelerin biyolojik etkilerini araştırmak önemlidir.

Anahtar kelimeler: Kitosan, Sitokin, irrigasyon solüsyonları, gingival fibroblast, propolis. 


\section{INTRODUCTION}

The success of endodontic therapy depends on its optimal performance as much as on the response of the patient's immune system. The tissue response is linked with the viability effect of the materials used for endodontic treatment, besides with the secretion of inflammatory cytokines. ${ }^{1}$ But this information is not clear because the cytokines are also important factors for tissue regeneration and regulating tissue inflammation. ${ }^{2}$

Microorganisms in the root canal system, microbial metabolism products, endotoxins as well as the materials used during endodontic treatment process activate the secretion of different inflammatory mediators (prostaglandins, cytokines, oxygenated intermediate products) from the surrounding cells. ${ }^{3,4}$ The biological properties of these materials are important because they may damage the periapical tissues, induce inflammation and alveolar bone resorption in the surrounding tissues when they are not biocompatible. The healing of periapical tissues after root canal treatment depends on the chemical composition of the endodontic materials and the degree to which the components break up into periapical tissues from these solutions. ${ }^{5}$

Since biological mediators provide information on the biological reactions that occur in the secretory region during periapical tissue healing process, therefore it is important to investigate the different cytokine secretion to determine the effect of the endodontic material on the cells. ${ }^{6,7}$

Although sodium hypochlorite $(\mathrm{NaOCl})$ is the most commonly used irrigation solution during endodontic process due to its high antibacterial and organic tissue dissolving effect, it has high toxicity. Thus, the search for an alternative irrigating solution to $\mathrm{NaOCl}$ continues that may provide break ground in reliable endodontic treatment. ${ }^{8}$

Chitosan is a polymeric material comprising $\mathrm{N}$-acetylglucosamine and glucosamine copolymer units, obtained from chitin by way of deacetylation and it is a natural polysaccharide. Chitosan is a kind of sugar that is made of the hard-outer skeleton of shellfish, such as crab, lobster, and shrimp. Other than being an irrigation solution it is used for so many purposes in endodontic treatment as removal of the smear layer and pulp capping. ${ }^{9-11}$

Propolis is a bee product obtained by mixing honey and sprouts collected from plants with resins, waxes and saliva secretions. Generally, propolis molecule consists of $50 \%$ resin and vegetable balsam, 30\% wax, 10\% essential and aromatic oils, $5 \%$ pollen and $5 \%$ other various substances (including organic debris depending on collection place and time). It has anti-inflammatory and antimicrobial properties. Propolis has been used as root canal irrigation solution and pulp capping material in endodontic treatment. Additionally, it is used in many fields of dentistry as karyology, oral surgery, periodontology, due to its nontoxic and biocompatibility properties. ${ }^{12-14}$

According to the literature, it is indicated that the fibroblast cells play an important role in biochemical reactions in which various cellular products are secreted, especially cytokines. ${ }^{15}$

Tumor necrosis factor- $\alpha$ (TNF- $\alpha$ ) and Interleukin-1 (IL-1) are common cytokines used to assess periapical inflammation and bone destruction. ${ }^{16}$ Since vascular endothelial growth factor (VEGF) is an effective cytokine in wound healing and bone regeneration, its release is closely related to the viability and function of the cells. ${ }^{17,18}$

The aim of this research is to evaluate the effects of $\mathrm{NaOCl}$ which is still commonly used in the endodontic treatment and the natural materials such as Propolis and Chitosan on the secretion of IL-1, TNF- $\alpha$ and VEGF cytokines on fibroblast and to provide data about whether these new materials can be an alternative to $\mathrm{NaOCl}$. The null hypothesis was that there would be no significant differences between the secretion of IL-1, TNF- $\alpha$ and VEGF cytokines on human gingival fibroblast with regard to propolis and chitosan.

\section{MATERIALS AND METHODS}

Sample preparation

Before starting the analysis, chitosan solution was prepared, $0.2 \mathrm{~g}$ of chitosan (Acros Organics, 90\% degree of deacetylation) was diluted in $100 \mathrm{~mL}$ of $1 \%$ acetic acid, and the mixture was stirred for $2 \mathrm{~h}$ using a magnetic stirrer. Propolis specimen was collected from Kayseri in Turkey and prepared based on previous studies.19

Another irrigation solution used in this study was $5 \% \mathrm{Na}$ $\mathrm{OCl}$ was commercially provided (Wizard, Directory Chemistry Industry and Trade Inc, Turkey).

Cell cultures

Human gingival fibroblasts (HGF-1; American Type Culture Collection, Manassas, VA; \#ATCC CRL-2014) was obtained through commercial sources for these studies. Cells were cultured in Dulbecco's Modified Eagles Medium (DMEM; Sigma Chemical Co., St. Louis, MO) supplemented with $10 \%$ Fetal bovine serum (Sigma, St. Louis, MO, USA), Penicillin (100 U/ml; Sigma, St. Louis, MO, USA), and Streptomycin (100 g/ml; Sigma, St. Louis, MO, USA) at $37^{\circ} \mathrm{C}$ in a humidified atmosphere of $5 \% \mathrm{CO} 2$ in air according to ATCC protocol. The culture medium was changed every 3 to 4 days.

There were 96-well plastic tissue culture plates (Linbro, Flow Laboratories Inc, McLean, VA) filled with 200 《l of medium containing $2 \times 104 \mathrm{hGFs}$ in each well. The plates were then incubated at $37^{\circ} \mathrm{C}$ in a humidified atmosphere $95 \%$ air containing 5\% CO2 for overnight to permit attachment of the cells to the plates. After $24 \mathrm{~h}$, the medium was removed, and confluent HGFs were rinsed with 200 $\mu \mathrm{l}$ phosphate buffered saline (PBS) three times. All mani- 
pulations of the specimens were performed under a laminar flow hood (Microtest) to avoid contamination from outside organisms.

The study groups were identified as it is seen 1: Human Gingival Fibroblast $+\mathrm{NaOCl}$ application, Group 2: Human Gingival Fibroblast + Propolis application, Group 3: Human Gingival Fibroblast + Chitosan application. Whole solutions were applied as described by stock concentration by half diluting to find the LD50 dose.

\section{Cytokine detection in culture}

Each group consisted of four wells. Cell culture plates were incubated for 2 hours at $37^{\circ} \mathrm{C}$ in a $5 \% \mathrm{CO} 2$ incubator. Levels of cytokines such as TNF- $\alpha$, IL-1 and VEGF (minimum detectable dose; 3 ng/L for TNF- $\alpha$; 1 ng/L for IL-1; 20 $\mathrm{ng} / \mathrm{L}$ for VEGF), were determined by specific ELISA techniques according to the manufacturer's instructions (Biotech, Shanghai, China). The concentration of cytokines was determined spectrophotometrically. The absorbance was read at $490 \mathrm{~nm}$ (Thermo Scientific Microplate Photometer, Multiskan FC, USA). We constructed a standard curve using cytokine standards. The cytokine concentrations for unknown samples were calculated according to the standard curve.

\section{Statistical Analysis}

Data analysis was performed using SPSS for Windows (version 15.0; SPSS Inc, Chicago, IL). Data were subjected to the Shapiro-Wilks test to characterize their normality. Because the samples did not present a normal distribution, the Kruskal-Wallis H-test was used to determine significant differences in samples from the same groups $(\mathrm{P}<$ 0.05). The Mann-Whitney test was used to compare the differences between the groups $(P<0.05)$. The level of significance was set at $\mathrm{P}<0.05$.

\section{RESULTS}

In this study, activation of IL-1 TNF- $\alpha$ and VEGF secretion on human gingival fibroblast of various solutions were evaluated in vitro.

Analysis of IL-1 secretion

IL-1 assay data shows that all prepared solutions activate IL-1 release as shown in Figure 1.

Solutions applied at the same effective dose (LD50) caused releasing different amounts of IL-1 in fibroblast and this difference was statistically significant $(P<0.05)$. According to the results of this analysis, IL-1 secretion was found highest in the group treated with $\mathrm{NaOCl}$ while the minimum level in the group treated with propolis (Figure 1).

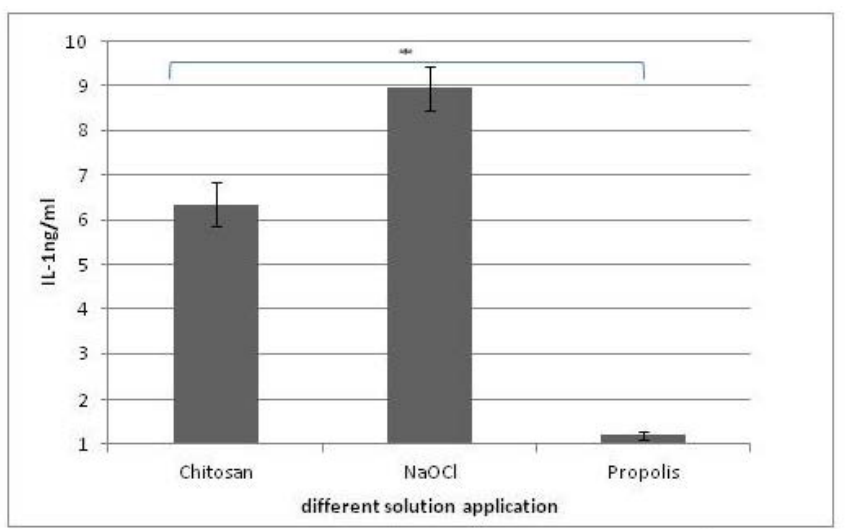

Figure 1. Columns represent the median values of IL-1 in pgm L-1. Symbol $(*)$ indicates the significant differences among 3 application groups $(P<0.05)$.

Analysis of TNF- $\alpha$ secretion

TNF- $\alpha$ assay data shows that all solutions activate TNF- $\alpha$ secretion indicated in Figure 2.

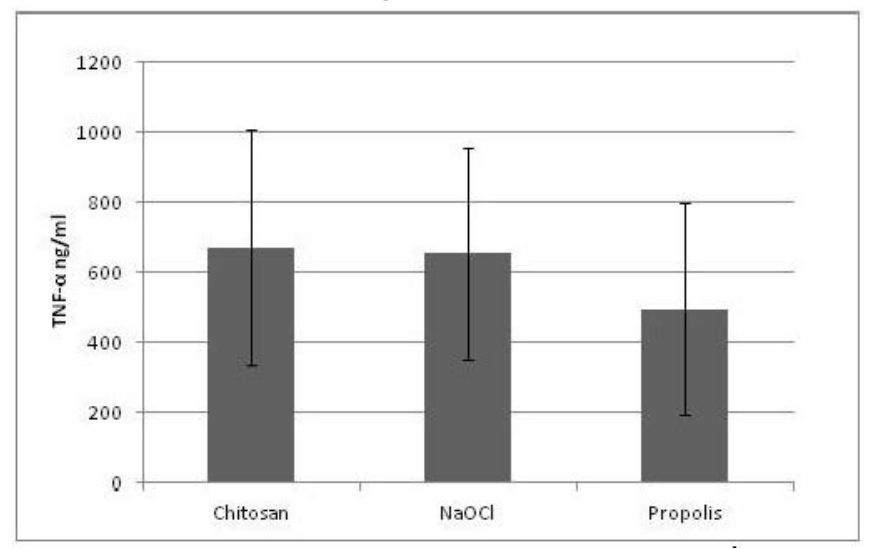

Figure 2.Columns represent the median values of TNF- $\nabla$ in pgm L-1. Symbol $(*)$ indicates the significant differences amongst groups $(P<0.05)$.

It was found that the solutions caused different amounts of TNF- $\alpha$ secretion in fibroblast, but this difference was not statistically significant $(P>0.05)$.

Analysis of VEGF secretion

VEGF assay data shows that all solutions activate VEGF secretion shown in Figure 3.

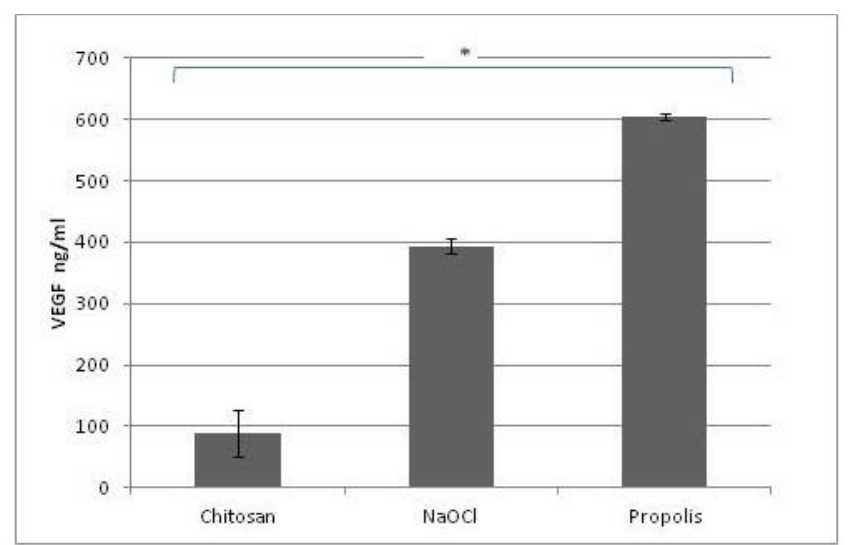

Figure 3.Columns represent the median values of VEGF in pgm L-1. Symbol $(*)$ indicates the significant differences amongst groups $(P<0.05)$.

These $\mathrm{NaOCl}$, Chitosan and Propolis implementation changed the level of VEGF secretion in (HGFS) fibroblast and this difference was statistically significant $(P<0.05)$. In accordance with these results, VEGF secretion was deter- 
mined the highest level in propolis group and lowest one in the chitosan group.

\section{DISCUSSION}

The results of the current study revealed that $\mathrm{NaOCl}$, Propolis, and Chitosan had not been similar to cytokine production $(\mathrm{P}<0.05)$. Therefore, the null hypothesis was not accepted. Studies have shown that root canal irrigation is an essential part of endodontic treatment and the biological effect of irrigation solutions after contact with the surrounding tissues are important for the success of the treatment. ${ }^{20,21}$ So, it is important to investigate this biological effect and the mediators that are secreted after the solutions contact with the surrounding tissues. However, the effect of irrigation solutions on the periapical immune response, specifically cytokine secretion, is not clear. ${ }^{6,22,23}$ IL-1 and TNF- $\alpha$ are important inflammatory cytokines which proide bone destruction induction during periapical diseases recovery. ${ }^{24}$ Besides these two cytokines, VEGF is an angiogenetic cytokine which can enhance the regeneration potential of periapical surronding tissues. ${ }^{25}$

All solutions used in this study activated the secretion of cytokines. Chitosan caused more TNF- $\alpha$ secretion numerically, but there was no significant difference between the solutions in terms of the TNF- $\alpha$ secretion. IL1 secretion was more in $\mathrm{NaOCl}$ group compared to Chitosan and Propolis group. Many researches have reported that chitosan and propolis are anti-inflammatory materials. ${ }^{21,26,27}$ Furthermore, research results found in different studies about the cell viability of these solutions, $\mathrm{NaOCl}$ has been found to be highly toxic although propolis and chitosan are biocompatible materials with no toxicity. ${ }^{28-30}$ The high level of IL-1 secretion in $\mathrm{NaOCl}$ group is may be explained by a higher toxicity of $\mathrm{NaOCl}$ of which may have an important role in initialization effect of enflammation process than that of propolis and chitosan, which are anti-inflammatory and angiogenetic materials.

Propolis has been described in a number of studies as a material that induces angiogenesis. ${ }^{31,32}$ Today, VEGF is known to be one of the main cytokines involved in angiogenesis. ${ }^{33,34}$ For this reason, propolis may induce more VEGF secretion compared to other solutions in accordance with the result of the study. In a study by Ahmadi et al. ${ }^{35}$, it was revealed that chitosan-based hydrogel did not induce angiogenesis. In addition, studies on chitosan have shown that angiogenesis is inhibited in various tumor cell lines. ${ }^{36}$

Considering that the VEGF is an angiogenic cytokine, the result of our study is correlated with these studies. However, in other studies, it has been reported that chitosan activates wound healing by increasing angiogenesis on various normal cell lines. ${ }^{37,38}$

The difference between our previous studies and our study may depend on the variety of cell lines used, the va- riability of the solution used, the difference in the method of obtaining chitosan, and the test method.

In endodontics, an ideal irrigation solution is biocompatible, as well as having antibacterial activity against microorganisms in root canals and solving organic and inorganic tissues. For this reason, we think that further studies should be done to evaluate these properties of these solutions.

\section{CONCLUSIONS}

Under the conditions of this study, the propolis and chitosan in the natural material group showed lower inflammatory cytokine secretion level than the $\mathrm{NaOCl}$ solution. In addition, propolis significantly increased VEGF secretion compared to other solutions.

\section{Conflicts of interest}

All authors disclose any potential sources of conflict of interest.

\section{REFERENCES}

1. Ciasca $M$, Aminoshariae A, Jin G, Montagnese T, Mickel A. A comparison of the cytotoxicity and proinflammatory cytokine production of EndoSequence root repair material and ProRoot mineral trioxide aggregate in human osteoblast cell culture using reverse-transcriptase polymerase chain reaction. J Endod 2012; 38: 486-489.

2. Kawashima N, Stashenko P. Expression of bone-resorptive and regulatory cytokines in murine periapical inflammation. Arc Oral Biol 1999; 44: 55-66.

3. Yang LC, Tsai CH, Huang FM, Liu CM, Lai CC, et al. Induction of interleukin- 6 gene expression by pro-inflammatory cytokines and black-pigmented Bacteroides in human pulp cell cultures. Int Endod J 2003; 36: 352-357.

4. Leprince J, Zeitlin B, Tolar M, Peters O. Interactions between immune system and mesenchymal stem cells in dental pulp and periapical tissues. Int Endod J 2012; 45: 689-701.

5. Melegari K, Botero T, Holland G. Prostaglandin E2 production and viability of cells cultured in contact with freshly mixed endodontic materials. Int Endod J 2006; 39: 357-362.

6. Gomes-Filho JE, Watanabe S, Gomes AC, Faria MD, Lodi CS, et al. Evaluation of the effects of endodontic materials on fibroblast viability and cytokine production. $J$ Endod 2009; 35: 1577-1579.

7. Neiva KG, Catalfamo DL, Holliday S, Wallet SM, Pileggi R. Propolis decreases lipopolysaccharide-induced inflammatory mediators in pulp cells and osteoclasts. Dent Traumatol 2014; 30: 362-367.

8. Önçağ Ö, Hoşgör M, Hilmioğlu S, Zekioğlu O, Eronat C, et al. Comparison of antibacterial and toxic effects of various root canal irrigants. Int Endod J 2003; 36: 423-432.

9. Silva P, Guedes D, Nakadi F, Pécora J, Cruz-Filho A. Chitosan: a new solution for removal of smear layer after root canal instrumentation. Int Endod J 2013; 46: 332-338. 
10. Ballal N, Kundabala M, Bhat K, Acharya S, Ballal M, Kumar R, Prakash P. Susceptibility of Candida albicans and Enterococcus faecalis to Chitosan, Chlorhexidine gluconate and their combination in vitro. Aust Endod $\mathrm{J} 2009$; 35: 29-33.

11. Liu X, Li Y, Zhao B. Experimental study on the effect of chitosan on dental pulp capping. Journal of Modern Stomatology 2001; 5: 008.

12. Bhandari $S$, Ashwini T, Patil CR. An in Vitro Evaluation of Antimicrobial Efficacy of $2 \%$ Chlorhexidine Gel, Propolis and Calcium Hydroxide Against Enterococcus faecalis in Human Root Dentin. J Clin Diagn Res 2014; 8: ZC60.

13. Al-Shaher A, Wallace J, Agarwal S, Bretz W, Baugh D. Effect of propolis on human fibroblasts from the pulp and periodontal ligament. J Endod 2004; 30: 359-361.

14. Gulinelli JL, Panzarini SR, Fattah CMRdS, Poi WR, Sonoda CK, et al. Effect of root surface treatment with propolis and fluoride in delayed tooth replantation in rats. Dent Traumatol 2008; 24: 651-657.

15. Takashiba S, Naruishi K, Murayama Y. Perspective of cytokine regulation for periodontal treatment: fibroblast biology. J Periodontol 2003; 74: 103-110.

16. Graves D, Cochran D. The contribution of interleukin-1 and tumor necrosis factor to periodontal tissue destruction. J Periodontol 2003; 74: 391-401.

17. Chu S-C, Tsai CH, Yang S-F, Huang F-M, Su Y-F, et al. Induction of vascular endothelial growth factor gene expression by proinflammatory cytokines in human pulp and gingival fibroblasts. J Endod 2004; 30: 704-707.

18. Leonardi R, Caltabiano M, Pagano M, Pezzuto V, Loreto $\mathrm{C}$, et al. Detection of vascular endothelial growth factor/ vascular permeability factor in periapical lesions. J Endod 2003; 29: 180-183.

19. Özan F, Polat ZA, Er K, Özan Ü, Değer O. Effect of propolis on survival of periodontal ligament cells: new storage media for avulsed teeth. J Endod 2007; 33: 570-573.

20. Hauman C, Love R. Biocompatibility of dental materials used in contemporary endodontic therapy: a review. Part 1. Intracanal drugs and substances. Int Endod $\mathrm{J}$ 2003; 36: 75-85.

21. Gomes-Filho JE, Aurélio KG, Costa MMTdM, Bernabé PFE. Comparison of the biocompatibility of different root canal irrigants. J Appl Oral Sci 2008; 16: 137-144.

22. Pappen FG, Souza EM, Giardino L, Carlos IZ, Leonardo MR, de Toledo Leonardo R. Endodontic chelators induce nitric oxide expression by murine-cultured macrophages. J Endod 2009; 35: 824-828.

23. Galler KM, Buchalla W, Hiller K-A, Federlin M, Eidt A, et al. Influence of root canal disinfectants on growth factor release from dentin. J Endod 2015; 41: 363-368.

24. Babel N, Cherepnev G, Babel D, Tropmann A, Hammer $\mathrm{M}$, et al. Analysis of tumor necrosis factor- $\alpha$, transforming growth factor- $\beta$, interleukin-10, IL- 6 , and interferon- $\gamma$ gene polymorphisms in patients with chronic periodontitis. J Periodontol 2006; 77: 1978-1983.

25. Mullane EM, Dong Z, Sedgley C, Hu J-C, Botero T, et al. Effects of VEGF and FGF2 on the revascularization of severed human dental pulps. J Dent Res 2008; 87: 11441148.

26. Azuma K, Osaki T, Minami S, Okamoto Y. Anticancer and anti-inflammatory properties of chitin and chitosan oligosaccharides. J Funct Biomater 2015; 6: 33-49.

27. Sabir A. The Effect of Propolis on Cytokines during Dental Pulp Inflammation. J Apic Res 2016; 31: 135-142.

28. Montoro A, Barquinero J, Almonacid M, Montoro A, Sebastià $\mathrm{N}$, et al. Concentration-dependent protection by ethanol extract of propolis against $\gamma$-ray-induced chromosome damage in human blood lymphocytes. Evid Based Complement Alternat Med 2010; 2011.

29. Hu P, Wang T, Xu Q, Chang Y, Tu H, et al. Genotoxicity evaluation of stearic acid grafted chitosan oligosaccharide nanomicelles. Mutat Res Genet Toxicol Environ Mutagen 2013; 751: 116-126.

30. Bajrami D, Hoxha V, Gorduysus O, Muftuoglu S, Zeybek ND, et al. Cytotoxic effect of endodontic irrigants in vitro. Med Sci Monit Basic Res 2014; 20:22.

31. Lima LD, Andrade SP, Campos PP, Barcelos LS, Soriani $F M$, et al. Brazilian green propolis modulates inflammation, angiogenesis and fibrogenesis in intraperitoneal implant in mice. BMC Complement Altern Med 2014; 14: 177.

32. Izuta H, Shimazawa M, Tsuruma K, Araki Y, Mishima S, et al. Bee products prevent VEGF-induced angiogenesis in human umbilical vein endothelial cells. BMC Complement Altern Med 2009; 9: 45.

33. Cross MJ, Claesson-Welsh L. FGF and VEGF function in angiogenesis: signalling pathways, biological responses and therapeutic inhibition. Trends Pharmacol Sci 2001; 22: 201-207.

34. Shibuya M, Claesson-Welsh L. Signal transduction by VEGF receptors in regulation of angiogenesis and lymphangiogenesis. Exp Cell Res 2006; 312: 549-560.

35. Ahmadi R, Burns AJ, de Bruijn JD. Chitosan-based hydrogels do not induce angiogenesis. J Tissue Eng Regen Med 2010; 4: 309-315.

36. Şalva E, Kabasakal L, Eren F, Özkan N, Çakalağaoğlu $F$, et al. Local delivery of chitosan/VEGF siRNA nanoplexes reduces angiogenesis and growth of breast cancer in vivo. Nucleic Acid Ther 2012; 22: 40-48.

37. Mizuno K, Yamamura K, Yano K, Osada T, Saeki S, et al. Effect of chitosan film containing basic fibroblast growth factor on wound healing in genetically diabetic mice. J Biomed Mater Res A 2003;64:177-181.

38. Guzmán-Morales J, El-Gabalawy H, Pham MH, TranKhanh N, McKee MD, et al. Effect of chitosan particles and dexamethasone on human bone marrow stromal cell os- 
teogenesis and angiogenic factor secretion. Bone 2009; 45: 617-626. 